\title{
Dairy goat production in the semi-arid region: productive and reproductive analysis, and the influence of the adoption of hygienic practices on milk quality
}

\begin{abstract}
[Produção de cabras leiteiras no semiárido: análise produtiva e reprodutiva, bem como
\end{abstract} influência da adoção de práticas higiênicas na qualidade do leite]

\author{
I.W.H. Silva ${ }^{(\mathbb{D})}$, J.F.P. Moura ${ }^{(\mathbb{D})}$, E. Santos Júnior ${ }^{\text {(D) , J.M. Pereira Filho }}{ }^{(\mathbb{D})}$, J.P.F. Oliveira ${ }^{1(\mathbb{D})}$, \\ T.P. Dias-Silva ${ }^{*}$ (D) L.R. Bezerra ${ }^{1}$ (D) \\ ${ }^{1}$ Universidade Federal de Campina Grande, Patos, PB, Brasil \\ ${ }^{2}$ Universidade Federal do Piauí, Bom Jesus, PI, Brasil
}

\begin{abstract}
The aim of this study was to evaluate the productive and reproductive performance of dairy goat genotypes, as well as the influence of hygienic practices by farmers on the quality of goat milk. Productive and reproductive data of 81 Anglo Nubian and Alpine crossbred goats, as well as data on total milk production of goats over 100 days of lactation and partial production up to 56 days of lactation. Also, in natura milk samples from 160 properties in the region were evaluated. At the time of collection, a questionnaire was applied to diagnose goat milk production systems. Data from productive and reproductive performance were evaluated by Tukey test and descriptive analysis using the SPSS program. The herd presented a variation of the total milk production in lactation (TMP) from $267.40 \mathrm{~kg}$ to $468.55 \mathrm{~kg}$, with lactation length ranging from 157 to 247 days, and average daily production between 1.43 and $1.89 \mathrm{~kg} / \mathrm{day}$. Fertility rates were satisfactory, with the lowest rate being $76 \%$ and the highest $92 \%$, with an average of $85.24 \%$ considering the six seasons of birth. The means of the gestation periods varied between 144 and 152 days. Regarding the sanitary characterization, $73 \%$ of farmers performed a cleaning of the room before and after milking. However, $94.8 \%$ of farmers did not eliminate the first jets of milk and only $29.2 \%$ used the screened mug test to identify clinical mastitis. Only $41 \%$ of farmers performed pre and post-dipping and $30.2 \%$ applied the iodine solution. Only $8.3 \%$ of farmers used disposable paper towels. However, $92 \%$ of producers still used fabric towel. It was also observed that $99 \%$ of the properties stored milk in buckets or cans without refrigeration. In the microbiological analysis, a small amount of milk samples (5.6\%) was contaminated with Staphylococcus aureus, however the total coliform count was high. Regarding the somatic cell count, it was found that $86 \%$ of the properties presented values above one million cells per $\mathrm{mL}$ of sample. The study demonstrated the prevalence of several factors that contribute to the vulnerability of milk contamination in various stages of production such as milking and processing. Thus, the guidance and awareness of those responsible is extremely important to improve goat milk quality in the semi-arid region of Paraíba.
\end{abstract}

Keywords: Anglo Nubian, lactation, milk contamination, performance, productive efficiency

\section{RESUMO}

O objetivo do presente estudo foi avaliar o desempenho produtivo e reprodutivo de genótipos caprinos leiteiros, assim como a influência da adoção das práticas higiênicas pelos produtores sobre a qualidade do leite caprino. A primeira parte da pesquisa foi realizada na Estação Experimental Pendência-PB. Foram analisados dados produtivos e reprodutivos de 81 cabras Anglo-Nubiana e alpinas mestiças, bem como dados de produção total de leite das cabras acima de 100 dias de lactação e produção parcial até 56 dias de lactação. Também foram avaliadas amostras de leite in natura de 160 propriedades da região. No momento da coleta, foi aplicado um questionário de diagnóstico dos sistemas de produção de leite caprino. Os dados de desempenho produtivo e reprodutivo foram avaliados pelo teste de Tukey e pela análise descritiva utilizando o

*Corresponding author: tairon.mvet@gmail.com

Submitted: March 17, 2021. Accepted: June 11, 2021. 
programa SPSS. O rebanho apresentou uma variação da produção de leite total na lactação desde $267,40 \mathrm{~kg}$ a 468,55kg, com durações de lactação variando de 157 e 247 dias, e produção média diária entre 1,43 e $1,89 \mathrm{~kg} /$ dia. As taxas de fertilidade foram satisfatórias, sendo a menor taxa de $76 \%$ e a maior de $92 \%$, com uma média de 85,24\% considerando as seis estações de parição. As médias dos períodos de gestação variaram entre 144 e 152 dias. Quanto à caracterização da sanidade, 73\% dos produtores realizam limpeza da sala antes e após a ordenha. No entanto, 94,8\% dos produtores não eliminam os primeiros jatos de leite e somente $29,2 \%$ utilizam o teste da caneca telada para identificação de mastite clínica. Apenas $41 \%$ dos produtores realizam pré-dipping e pós-dipping e 30,2\% aplicam a solução de iodo. Somente $8,3 \%$ dos produtores usam toalhas descartáveis e $92 \%$ ainda utilizam toalha de tecido. Observou-se, ainda, que 99\% das propriedades armazenam o leite ordenhado em baldes ou latões, sem refrigeração. Pequenas quantidades de amostras $(5,6 \%)$ estavam contaminadas por Staphylococcus aureus, porém a contagem de coliformes totais teve valor elevado. Em relação à contagem de células somáticas, verificou-se que $86 \%$ das propriedades apresentaram CCS acima de um milhão de células por $m L$, devendo-se ajustar corretamente os manejos alimentar, produtivo e reprodutivo. As épocas de parição, lactação e o genótipo influenciaram de forma direta os índices produtivos e reprodutivos dos animais. Obsevou-se a prevalência de vários fatores que contribuem para a vulnerabilidade de contaminação do leite em diversas etapas de produção, tais como ordenha e processamento. Portanto, a orientação adequada e a conscientização dos responsáveis são de extrema importância para melhorar a qualidade do leite de cabra na região semiárida da Paraíba.

Palavras-chave: Anglo-Nubiano, contaminação do leite, desempenho, eficiência produtiva, lactação

\section{INTRODUCTION}

Efficiency in the goat milk production in Northeastern of Brazil is directly linked to wellplanned and organized production systems, being the region with the highest milk production due to the large number of animals, which according to the Brazilian Institute of Geography and Statistics (Censo..., 2017), concentrates $92 \%$ of the national goat herd. The exploitation of goat farming is explained by the high adaptive capability to the semi-arid edaphoclimatic conditions and to the most varied types of management carried out by farmers. These good results even appear when farmers seek technological advances facing the Brazilian semiarid region.

In arid semi-arid regions, goats are among the most suitable ruminants for milk production, due to their ability to adapt to characteristic climatic conditions and are able to produce and reproduce under these conditions (Maia et al., 2010). This animal production capacity usually expands from Agreste to Sertão, being more resistant to drought than other species (Tecnologia..., 2014). Economically, the goat milk production enables small and medium farms, participating in the composition of family income, fixing man to the rural environment and improving the nutritional conditions of the population (Richards et al., 2001). For Mota et al. (2010), milk is an insertion factor of family farmers in the producer market, being, therefore, one of the most important rural activities for small farmers. Almeida et al. (2016) point out that the emergence and progress of the dairy basin are of a complex nature and of rapid and profound changes regarding the conditions of productivity and valuation of milk, highlighting the strong adaptability of small farmers to the market and to developments in the technological context. These transformations occur in a non-similar way, due to the difference of situations encountered and which demand diversified forms of support. Worldwide, a major concern is observed with the production and especially to encourage the consumption of goat milk and derivatives, which from a nutritional standpoint, is a rich food, constituting an important source of protein, phosphate and calcium in food in underdeveloped countries (Park, 1991). Thus, the knowledge of the factors that affect the nutritional composition of milk is particularly important for food to reach the consumer safely (Portugual et al., 2002). Brazilian milk production still has many aspects to be improved, mainly regarding the quality of milked milk, as well as the administrative and financial management of the activity (Simões et al., 2015).

In this scenario, seeking to achieve better production rates, the choice of the herd is very important in any production system. Alternatively, goat milk farmers are seeking genetic improvement through the Anglo Nubian and Alpine breeds (Saanen and Alpine Brown), in the expectation that animals can express their 
productive and reproductive capacity. The goat breeds exploited in Brazil for milk production are Saanen, Alpina and their crosses (Cardoso et al., 2015) as well as Anglo Nubian (Nascimento and Souza, 2011).

In small farms, beyond the production capacity, feed management is essential. For this, it is necessary to adopt strategies to meet the nutritional requirements of animals in the different stages of production. Strategies like implementation of areas with palm trees and grasslands, combined with the preservation of the Caatinga in the sense of promoting a differential in milk derivatives as highlighted by Medeiros et al. (2013). In addition, grazing in the Caatinga area represents, as shown by Silva and Medeiros (2003), a substantial supply of feed for dairy goats throughout the year in commercial units in the semi-arid region of Paraíba, therefore, its use would not be restricted only to the dry season of the year.

Hygienic practice adoption is necessary for maintenance of milk quality and it must begin with monitoring the animal's health, proper milking hygiene, equipment and utensils as well as the cleaning and disinfection of the teats (Tronco, 2008). Also, there should be no distinction between the types of milk in terms of health quality, only vary in acceptable microbiological standards, in accordance with current legislation. To implement improvements in quality control, it is important to seek a set of decisions and technical standards applied to the use of productive factors, as labor, land and capital, to obtain milk, in an environmental, social and economically sustainable way.

Given the above, the study was conducted aiming to evaluate the productive and reproductive performance of different genotypes of dairy goats in the semiarid, and also obtain data regarding the microbiological and physicalchemical quality of the goat's milk produced and verifying that the milk complies with current legislation standards.

\section{MATERIAL AND METHODS}

The study was carried out between the months of January 2017 and December 2018, at the Experimental Station Pendência, belonging to the State Company of Agricultural Research of
Paraíba (EMEPA-PB), located in the Mesoregion of Cariri paraibano, Microregion of Curimataú Ocidental, municipality of Soledade ( $7^{\circ} 8^{\prime} 18^{\prime \prime} \mathrm{S}$ e $36^{\circ} 27^{\prime} 2^{\prime \prime} \mathrm{W}$ ), with an altitude of $534 \mathrm{~m}$. Based on the Köppen classification, the climatic type of the region is Bsh, a hot semi-arid region, with rains from January to April, and annual average temperatures around $24^{\circ} \mathrm{C}$, relative humidity around $68 \%$, an average annual rainfall of $400 \mathrm{~mm}$ and water deficit during almost the whole year.

The Ethics Committee for Animal Experimentation (ECAE) of Federal university of Campina Grande approved the procedures herein performed on animals (license number: CEP/CEUA n $\left.{ }^{\circ} 110-2018\right)$. For implementation of this experimental study, an area of 20 ha was duly fenced and with respective divisions, with areas of implanted buffel grass and Caatinga. The forage support was based on four components: buffel grass (Cenchrus ciliares), forage palm (Nopalea cochenillifera SalmDyck.), forage sorghum (Shorgum bicolor L. Moench) and the Caatinga vegetation. The areas with buffel grass, totaling 7.0ha, were destined both for grazing and for making hay. Along with buffel grass (grazing and hay) and silage sorghum, the forage palm formed the basis for supplying roughage in the research.

The goats that started the composition of the herd were crossbred alpine especially the Alpine Brown, having been acquired from a breeder of a neighboring municipality, without any information on productivity, birth order or other information relevant to milk production. Then, Saanen and Anglo Nubian crossbred goats were added to the herd, under the same conditions regarding the productive and reproductive history.

The rams used in the first year of the system also had no reference to the production of genealogy who maintained a presumably high genetic value for milk production. Only from the second year onwards, rams with a high level of milk production were introduced and the goats were discarded, guided by the production level.

Eighty-one Anglo Nubian and Alpine crossbred goats were used, which were evaluated in six lactation stations and distributed as follows: station 1: 12 goats, station 2: 23 goats, station 3: 
12 goats, station 4: 09 goats, station 5: 07 goats, and station 6: 18 goats. For reproductive rates, reproductive data from 138 goats of the two genotypes exposed to the experiment were analyzed, in 6 breeding stations, distributed as follows: station 1: 34 goats, station 2: 17 goats, station 3: 26 goats, station 4: 24 goats, station 5: 13 goats, station 6: 24 goats.

The production system adopted was semiintensive in which the goats spent part of the day in the buffel grass area and another part in the management center, where they received supplementation containing concentrated, roughage and mineral supplement, according to their nutritional requirements. For lactating goats, a diet was formulated based on the level of production. The other categories received a diet according to their average live weight and their physiological state (19 to $20 \%$ crude protein in total dry matter).

The non-pregnant goats were kept on grazing, supplemented with multiple mix or nutritional blocks, for a period of three weeks before the breeding season until the end of the breeding season. Goats of first parturition received special care in the final third of gestation, and if they came from early mating (8-12 months) they were kept separate from multiparous goats with better quality feed, following their body condition, increasing supplementation in body condition less than 2.0 or 2.5. Two weeks before the parturition, the pregnant goats were separated from the herd and placed in paddocks maternity to facilitate the monitoring and interventions needed at this stage.

After birth, the offspring received initial care, suckled colostrum and were separated from their mothers. From day 3, the offspring were suckled in a collective bottle with goat's milk or with bovine milk substitute, in two daily feedings. From the 15th day, a diet based on concentrate and Tifton hay was offered. After weaning (two months), the offspring were separated from the adults, with voluminous feeding based on buffel grass, under grazing system (in the rainy season), sorghum silage, hydrolysed sugarcane and forage palm.

The rams were fed the same roughage available to the goats, but with a concentrated diet with 14 to $16 \%$ crude protein. The reproductive management was planned in order to achieve the goal of three calving seasons per year, distributed in the months of December, April and August. The goat batches distribution was carried out according to the breeding season. Throughout the period from 2017 to 2018, this procedure occurred as follows: breeding seasons in July, November, March, with lambing stations in December, April and August, respectively.

In the initial formation of the herd of Anglo Nubian goats (acquisition in EMEPA) the condition for the incorporation in the herd was restricted only to age, in which were accepted goats with 2-4 years old. At the beginning of the implantation of the system, pure rams of origin of each genotype belonging to EMEPA were used: Anglo Nubian and Alpine Brown.

In young animals, deworming (orally) occurred at 28 days after birth with repetition at 21 days after the previous deworming. Then, the animals were monitored and evaluated using the Famacha $₫$ method. Adult goats were dewormed one week before the breeding season and were monitored monthly by mucosa evaluation and faecal egg count (Thienpont et al., 1986).

Milking was performed daily manually, using routine standards such as cleaning and disinfecting the teats, black background Mug test, pre dipping, drying teats with paper towels, post dipping and milk pasteurization, storage and processing, and cleaning of milking utensils.

The zootechnical bookkeeping consisted of the control notes of the herd, with individual tokens per animal, registering their genealogy, occurrences and performance. In the notes, the dates, the body score condition and the important occurrences such as birth, mating, diseases, death, disposal, control of the feed provided (concentrated, forage and mineral) were recorded, productive performance rates such as herd weight per month and young animals every 20 days until weaning at 60 days. Among other important measurements, such as milk control every 7 days, analysis of the chemical composition of milk, performed twice per lactation station.

Total milk production (TMP), partial milk production at 56 days (PM56), average daily milk production (ADMP), and lactation length 
(LL) were evaluated. To calculate TMP, the production of goat's milk, obtained from dairy control, was multiplied by 7 (Doney et al., 1979). The averages were calculated using the total amount of milk divided by the days of lactation. In partial production, controls were multiplied by 7 until 56 days of lactation. The reproductive variables such as fertility, prolificacy, gestation period, number of abortions, mating weight and weight of goats at parturition were analyzed.

The samples were collected monthly, during a 24-month period, in four mini goat milk processing plants, samples of fresh milk from the containers provided by 160 family farmers in Cariri Paraibano. At the time of sample collection, a questionnaire was applied to carry out the diagnosis of goat milk production systems in the region, in which aspects related to the owner profile were addressed such as characterization of the facilities and the herd, nutritional and health management, milking procedures, as well as information on the origin and treatment of the water used.

The total coliform count in goat milk was performed according Apha (1992), with plates that showed 25 to 250 colonies with the aid of a magnifying glass $(10 \mathrm{x})$, and the results were expressed in colony-forming unit (CFU) per $\mathrm{mL}$ of sample. The detection and quantification of Staphylococcus spp. and Staphylococcus aureus were performed according to Bennett and Lancette (1998). After counting, three typical and three atypical colonies were selected and transferred to brain and heart Infusion broth and incubated at $37^{\circ} \mathrm{C}$ for 24 hours.

The somatic cell count (SCC) was performed by direct microscopy as described by Prescott and Breed (1910), using the dye-containing pyronin Y. The smears were made using a volume of $10 \mu$ of goat milk (in duplicate) in an area of $1 \mathrm{~cm}^{2}$ on glass plate previously cleaned and degreased.

The profile of the farmers and the family-based goat milk properties in Cariri Paraibano was identified through the application of individual questionnaires adapted by Moura (2009).
The data were analyzed by the GLM procedure of the software SAS® (9.2) using appropriate statistical models for each group of characteristics. Milk production, genotype and birth season were considered as sources of variation, and when significant, were subjected to Tukey test. In the analysis of Pearson's correlations, the CHI-SQUARE procedure of SAS 9.2 was used. For descriptive analyzes the SPSS program (17.0) was used. For all characteristics, a significance level of $5 \%$ probability was used.

\section{RESULTS AND DISCUSSION}

In the evaluation of the production rates, which included records of milk production from six production stations, three in 2017 and three in 2018 , the herd showed a variation in TMP of 261.2 to $466.8 \mathrm{~kg}$, with LL ranging from 157 to 247 days and ADMP between 1.43 and $1.89 \mathrm{~kg} /$ day. There was a tendency to improve productivity over time, as the goats became more specialized (Table 1).

Investments in dairy genetics with the use of rams from the South African embryo import program, selective discards and adjustments in health and feed management resulted in a constant improvement in productivity. This deficiency was linked to the difficulties imposed by the six-year drought and by the limitation in commercial management, as the sale of milk depended on unreliable and very inconsistent purchasing schemes. On the other hand, it is important to emphasize that it is fully possible to achieve remarkable advances in the productivity of the herd, even in conditions as adverse as those that characterize this long period of drought, between the years 2012 and 2017 in the region. A total production of $468 \mathrm{~kg}$ in lactation can promote a profitability that allows a comfortable condition for a family, even more when considering that this activity should not be exclusive, being an additional complement for the generation of income. It is worth remembering that activity diversification is one of the characteristics of family farming production units in the semiarid region. 
Table 1. Total and partial milk production, average daily milk production and lactation length stations and goat genotypes

\begin{tabular}{|c|c|c|c|c|c|}
\hline Genotype $(\mathrm{G})$ & $\mathrm{N}$ & TMP $(\mathrm{kg})$ & ADMP (kg/dia) & LL (dias) & PM56 (kg) \\
\hline crossbred Alpine & 41 & $346.50 \mathrm{a}$ & $1.75 \mathrm{a}$ & $198 \mathrm{a}$ & $124.24^{\mathrm{a}}$ \\
\hline Anglo Nubian & 40 & $230.79 b$ & $1.47 \mathrm{~b}$ & $157 \mathrm{~b}$ & $107.18 \mathrm{~b}$ \\
\hline \multicolumn{6}{|l|}{ Lactation Station (LS) } \\
\hline $1^{a}$ & 12 & $326.36 \mathrm{~b}$ & 1.64 & $199 \mathrm{abc}$ & $114.42 \mathrm{ab}$ \\
\hline $2^{a}$ & 23 & $262.19 \mathrm{~b}$ & 1.67 & $157 \mathrm{bc}$ & $124.02 \mathrm{ab}$ \\
\hline $3^{a}$ & 12 & $261,29 b$ & 1.43 & $183 \mathrm{c}$ & $93.62 \mathrm{~b}$ \\
\hline $4^{a}$ & 9 & $404.06 \mathrm{ab}$ & 1.78 & $227 \mathrm{ab}$ & $129.57 \mathrm{ab}$ \\
\hline $5^{a}$ & 7 & $290.68 b$ & 1.69 & $182 \mathrm{bc}$ & $124.26 \mathrm{ab}$ \\
\hline $6^{\mathrm{a}}$ & 18 & $466.83 \mathrm{a}$ & 1.89 & $247 \mathrm{a}$ & $131.49^{\mathrm{a}}$ \\
\hline \multicolumn{6}{|l|}{ Significance } \\
\hline Genotype & & * & $*$ & * & * \\
\hline Lactation Station & & $*$ & ns & $*$ & $*$ \\
\hline $\mathrm{G} \times \mathrm{LS}$ & & $\mathrm{ns}$ & $\mathrm{ns}$ & $*$ & Ns \\
\hline
\end{tabular}

N-Number of observations; TMP-Total milk production; ADMP-average daily milk production; LL-Lactation length; PM56-Partial milk production during lactation.

*-significant at $5 \%$ probability; ns-not significant.

Means followed by different letters in columns differ by Tukey test $(\mathrm{P}<0.05)$.

However, it is possible to design higher milk production, especially considering an increase in the lactation length. If the maximum duration of lactation length ( 247 days) is increased by $20 \%$, an index of 296.4 days would be reached, generating a total milk production per lactation, or annual, of $560 \mathrm{~kg}$, maintaining the average daily production obtained in the sixth production season. In this context, Alpine crossbred goats had a higher average lactation length (DL) (11.86\%) than Anglo Nubian goats, which was already expected due to the greater specialization of the Alpine breed for milk production. These values are higher than the reported by Facó et al. (2007) who worked with Anglo Nubian dairy goats in a semi-intensive system and observed a lactation length of approximately 141 days. However, the lactation length observed in this study was lower than Alpine and Saanen goats in southeastern region (211 days) (Irano et al., 2012). If it was compared the results with those reported by Santos and Santana (2011), who found LL averages of 168 and 251 days for the Anglo Nubian and Saanen breeds, respectively, it appears that the survey means follow the trend of genotypes. However, these rates are below what is desirable for the exploration of specialized goats, mainly in a system that recommends one birth per year. In other words, non-lactating goats are only generating expenses, which is not interesting in dairy farming. It should be emphasized that the system has been employing dairy rams with greater milk potential, expecting higher lactation length in the next generations.

The sixth lactation station had a low coefficient of variation for TMP, suggesting that the batch goats, in this station, were probably more homogeneous. It should be remembered that the division of the herd into 06 (six) batches for parturition in April, August and December, guarantees the regularity of milk production throughout the year, since the moment a batch starts to drop production, another batch is starting lactation, with production practically stable in all months.

Alpine crossbred goats presented a TMP of 23.96\% higher than Anglo Nubian. The lowest average of Anglo Nubian can be explained by its dual purpose and the fact that the first goats were not subjected to a selection process. Although the first Alpine crossbred goats also did not come from a selection process, but Alpine breeders with recognized dairy potential were used from the 4th season onwards.

It must be emphasized that the use of genetically improving breeding animals is also necessary in a second step in small family farms, due to their limited capital when beginning the dairy activity. This strategy of using dairy rams on small farms is very dependent on the availability of animals belonging to the farmers in the surroundings who have already started the activity for a long time 
as recorded by Riet-Correa et al. (2013). In a study with dairy Anglo Nubian goats, Facó et al. (2007) observed an average production of 168.67 $\mathrm{kg}$, attributing the low milk performance to the short lactation length (140.79 days). These averages (TMP and LL) are lower than those observed in the present study.

Even with Alpine crossbred goats having a higher production capacity, it is still far from what could be considered ideal, especially when combining the low lactation length, reflecting a total milk production below what is necessary to promote a more rewarding profitability.
Throughout the lactation stations, there was a trend towards an increase in ADMP, achieved using better rams and the practice of selective disposal based on the results of milk control. The last station was hampered by the succession of years of drought, which caused a deficient supply of nutrients for the herd, was the one with the best ADMP. This, probably, it was due to a genetic improvement of the herd in the experiment.

There was a significant difference $(\mathrm{P}<0.05)$ in the birth order on TMP, PM, ADMP and LL (Table 2).

Table 2. Total and partial milk production, average daily milk production and lactation length as a function of lactation stations and birth order.

\begin{tabular}{lcc}
\hline \multirow{2}{*}{ Variables } & \multicolumn{2}{c}{ Category } \\
\cline { 2 - 3 } & Primiparous & Multiparous \\
\hline Number of observations & 31 & 50 \\
Total milk production $(\mathrm{kg})$ & $257.25^{\mathrm{b}}$ & $352.23^{\mathrm{a}}$ \\
Average daily milk production (kg/day) & $1.47^{\mathrm{b}}$ & $1.77^{\mathrm{a}}$ \\
Lactation length (days) & $175^{\mathrm{b}}$ & $199^{\mathrm{a}}$ \\
Partial milk production during lactation $(\mathrm{kg})$ & $102.06^{\mathrm{b}}$ & $129.08^{\mathrm{a}}$ \\
\hline
\end{tabular}

Means followed by different letters differ by Tukey's test at $5 \%$ probability.

Primiparous goats showed lower averages for all variables (TMP, ADMP, LL and PM56) compared to multiparous goats. This behavior was expected since in primiparous goats the nutrients are distributed to body development and maintenance of pregnancy. Carnicella et al. (2008) described higher yields of goats' milk from third and fourth birth order. Generally, with the increase in service life, there is a tendency to increase milk production, reaching its maximum production (Irano et al., 2012).

The correlation was positive $(\mathrm{P}<0.05 ; 0.66)$ between the TMP and PM after 56 days of lactation (PM56) indicating that can be performed a preliminary assessment of the productivity of goats at PM56. This information can assist in making decisions for future disposal before the animals end their lactation period. Earlier disposal benefits the whole system by improving reproductive and productive rates and avoiding higher costs with low productive animals.

The herd fertility rates were satisfactory (Table 3 ), with the lowest rate being $76 \%$ and the highest $92 \%$, with an average of $85.24 \%$ considering the six birth stations, which was higher than $80.4 \%$ found by Medeiros et al. (2006).

The abortion rate in the first breeding season was $20.68 \%$, which is an acceptable value within the abortion range for the semi-arid edaphoclimatic conditions. The abortion rate was higher than rates of the following stations, with abortion rate of $0 \%$ from the second breeding season, as a result of the adjustment in feed management. Another index that showed importance for the system was the rate of prolificacy, which in this study ranged from 1.21 to 1.71 , being that the lowest rate occurred in the first breeding season when the goats were under feed restriction and in inadequate body condition for conception. The average of the experiment prolificacy rate was 1.5 , a result similar to that found by Medeiros $e t$ al. (2006).

The gestation periods ranged between 144 and 152 days, probably due to factors such as age of the herd and the time of year. This fact was verified by Medeiros et al. (2006) and Facó et al. (2007) in Anglo Nubian goats. However, Alpine goats did not presented influence by the year of birth (Facó et al., 2007). 
Table 3. Reproductive rates of goats according to the breeding season

\begin{tabular}{lcccccc}
\hline \multirow{2}{*}{ Rates } & \multicolumn{7}{c}{ Breeding season } \\
\cline { 2 - 7 } & 1 st & 2nd & 3rd & 4 th & 5 th & 6 th \\
\hline Goats mated & 34 & 17 & 26 & 24 & 13 & 24 \\
Pregnant goats & 29 & 13 & 24 & 21 & 11 & 23 \\
Non-pregnant goats & 5 & 4 & 2 & 3 & 2 & 1 \\
Parturient goats & 23 & 13 & 24 & 20 & 10 & 23 \\
Abortions & 6 & 0 & 0 & 1 & 1 & 0 \\
Fertility (\%) & 85.2 & 76 & 92 & 88 & 85 & 92 \\
Prolificacy & 1.21 & 1.61 & 1.66 & 1.71 & 1.60 & 1.30 \\
Gestation period (days) & 152 & 148 & 144 & 148 & 149 & 149 \\
Body condition score in mating & 2.5 & 2.5 & 2.4 & 2.7 & 2.3 & 2.5 \\
Body condition score at birth & 1.5 & 1.5 & 2,0 & 2.5 & 2.1 & 2.3 \\
Goat weight in mating & 33.5 & 37.2 & 42.6 & 33.2 & 40.7 & 44.1 \\
Goat weight at birth & 37 & 46.5 & 49 & 43.5 & 44.7 & 51.2 \\
\hline
\end{tabular}

Higher fertility and prolificacy rates were found in Anglo Nubian goats $(100 \%$ and 1.80$)$ compared to crossbred Alpines (81\% and 1.57), but both genotypes showed high rates. These are important parameters for increasing the scale of animal production from the point of view of reproductive efficiency. These high rates can be justified by the correct nutrition of the goats using feeding management practices such as flushing to meet the nutritional requirements of goats during the pregnancy. It is noteworthy that the high reproductive rates obtained were in times of low rainfall, where the average annual rainfall was $239.35 \mathrm{~mm}$. These results of prolificacy and fertility are those that are sought to produce goat milk in an alternative system in the semiarid region.

Most farmers (51.2\%) have goat farming as the only source of family income, which shows the practice of other activities that participate in income. Regarding the housing, $80.6 \%$ live in the rural property and $93.2 \%$ have some level of education (complete or incomplete) (Table 4).

The number of properties that performed the forage conservation was lower $(28.8 \%)$ than the data presented by Bandeira et al. (2007), who observed that $60 \%$ of family farmers in Cariri Paraibano used hay and/or silage as an alternative in the period of feed scarcity. In relation to the reproductive management of herds, it was observed that $50.6 \%$ carry out controlled breeding. The characteristic behavior of the female during estrus is the main indicator $(64.4 \%)$ used by farmers for mating. There was a high occurrence $(98.1 \%)$ of estrus repetition reflecting low reproductive rates.

It was observed that $72.9 \%$ of farmers perform cleaning of the room before and after milking. However, $94.8 \%$ of farmers do not eliminate the first jets of milk and only $29.2 \%$ use the screened mug test to identify animals with clinical mastitis. Only $41.6 \%$ of producers perform predipping, $40.6 \%$ post-dipping and $30.2 \%$ only apply the iodine solution to disinfect the teats. It was found that only $8.3 \%$ of producers use disposable paper towels to dry the teats after washing. However, $92 \%$ of producers still routinely use a cloth towel to dry the goats' teats. About $43.8 \%$ and $47.9 \%$ of family farms have one and two milkers to perform the service, respectively, and $99 \%$ milked the animals manually. It was also observed that $99 \%$ of the properties store the milk milked in buckets or cans, without refrigeration. The analysis of the data resulting from the application of questionnaires showed that the dissemination of technical knowledge related to quality promotion has shown results when compared to previous years. 
Dairy goat production...

Table 4. Characterization of the goat milk production by family farmers in Cariri Paraibano

\begin{tabular}{|c|c|c|}
\hline Variables & Number of family farmers & Percentage value $(\%)$ \\
\hline \multicolumn{3}{|l|}{ Educational level } \\
\hline Not literate & 11 & 6.9 \\
\hline Some type of education & 149 & 93.1 \\
\hline \multicolumn{3}{|c|}{ Performs other activities in addition to the goat farming? } \\
\hline Yes & 78 & 48.8 \\
\hline No & 82 & 51.2 \\
\hline \multicolumn{3}{|l|}{ Performs the forage conservation? } \\
\hline Yes & 46 & 28.8 \\
\hline No & 114 & 71.2 \\
\hline \multicolumn{3}{|l|}{ What reproductive management is adopted? } \\
\hline Natural breeding & 79 & 49.4 \\
\hline Controlled breeding & 81 & 50.6 \\
\hline \multicolumn{3}{|l|}{ Do goats have repetition of estrus? } \\
\hline Yes & 3 & 1.9 \\
\hline No & 157 & 98.1 \\
\hline \multicolumn{3}{|l|}{ Milking hygiene processes } \\
\hline Room cleaning before milking & 117 & 72.9 \\
\hline Milker hygiene is performed & 160 & 100.0 \\
\hline The screening test mug is used & 47 & 29.2 \\
\hline The first jets of milk are not discarded & 152 & 94.8 \\
\hline Performs teats washing & 67 & 41.6 \\
\hline Iodine solution is used & 48 & 30.2 \\
\hline Paper towel is used & 13 & 8.3 \\
\hline Fabric towel is used & 147 & 91.6 \\
\hline Disinfection of teats after milking is performed & 65 & 40.6 \\
\hline Clean room cleaning before milking & 118 & 73.9 \\
\hline \multicolumn{3}{|l|}{ Milk Storage } \\
\hline Buckets or cans & 158 & 99.0 \\
\hline Cooling tank & 2 & 1.0 \\
\hline \multicolumn{3}{|l|}{ Collection and transport of milk } \\
\hline Buckets or cans & 160 & 100.0 \\
\hline
\end{tabular}

The results regarding the contamination levels for coliforms at $30-35^{\circ} \mathrm{C}$ of the samples of fresh goat milk produced by family farmers in Cariri Paraibano, showed a count between zero and $2 \times$ $107 \mathrm{CFU} / \mathrm{mL}$ (Table 5). Similarly, Gottardi et al. (2008) found a variation of total coliforms between zero and $1.4 \times 106 \mathrm{CFU} / \mathrm{mL}$ for goat milk. The high concentration of these microorganisms negatively impacts milk quality, since they are the main acidifying agents, determining milk return and low yield in the production of dairy products.

Arq. Bras. Med. Vet. Zootec., v.73, n.5, p.1147-1158, 2021
In the microbiological analysis, a small amount of milk samples $(5.6 \%)$ were contaminated with Staphylococcus aureus. The concentration of enterotoxin capable of causing symptoms of intoxication can occur when the number of $S$. aureus exceeds $105 \mathrm{CFU} / \mathrm{mL}$ (FDA, 1992). Count higher than $105 \mathrm{CFU}$ were observed in 2 $(2.1 \%)$ of the properties studied. The SCC ranged from 233.420 to 6.039 .743 with an average of 2.553 .890 cells $/ \mathrm{mL}$. The mean CCS verified in this study was lower than that verified by Min et al. (2007) and higher than that found by Cordeiro et al. (2002) in Rio Grande do Sul, which reached a value of $1.74 \times 106$ cells $/ \mathrm{mL}$. 
Table 5. Contamination levels of in natura goat milk of Cariri Paraibano in relation to the ranges of values for coliforms at $30-35^{\circ} \mathrm{C}(\mathrm{CFU} / \mathrm{mL})$

\begin{tabular}{lcc}
\hline Coliform contamination $(\mathrm{CFU} / \mathrm{mL})$ & Number of samples & Percentage value $(\%)$ \\
Up to $10^{4}$ & 111 & \\
From $10^{4}$ to $5 \times 10^{5}$ & 29 & 18.4 \\
From $5 \times 10^{5}$ to $10^{6}$ & 04 & 2.5 \\
Bigger than $10^{6}$ & 16 & 10.0 \\
Total & 160 & 100 \\
Contamination by Staphylococcus spp. (CFU/mL) & & \\
Up to $10^{4}$ & 97 & 60.6 \\
From $10^{4}$ to $5 \times 10^{5}$ & 35 & 21.9 \\
From $5 \times 10^{5}$ to $10^{6}$ & 10 & 6.3 \\
Bigger than $10^{6}$ & 18 & 11.3 \\
Total & 160 & 100 \\
Somatic cell count (cell/mL) & & 14.1 \\
Up to $10^{6}$ & 19 & 47.4 \\
From $10^{6}$ to $2 \times 10^{6}$ & 64 & 27.4 \\
From $2 \times 10^{6}$ to $2 \times 10^{6}$ & 37 & 11.1 \\
Bigger than $4 \times 10^{6}$ & 15 & 100 \\
Total & 135 & \\
\hline
\end{tabular}

\section{CONCLUSIONS}

The birth season, lactation and the genotype directly influenced the productive and reproductive rates of the goats. Feed, productive and reproductive management must be properly adjusted in order to reduce the indirect effects of the climate on Alpine goats, seeking to express the productive potential. Also, a small production unit (20 hectares) can be carried out by family farmers in the northeastern semi-arid region, maintaining regular production using simple procedures.

\section{ACKNOWLEDGMENTS}

The authors would like to thank the Federal University of Campina Grande (UFCG), the Center for Health and Rural Technology (CSTR), the Animal Science Program and the Coordination for the Improvement of Higher Education Personnel (CAPES) for the financial support.

\section{REFERENCES}

ALMEIDA, B.; SILVA, E.; SILVA, F. Impacto da produtividade leiteira e qualidade morfológica das vacas leiteiras na rentabilidade económica das explorações. Rev. Ciênc. Agr., v.39, p.291299, 2016.

\section{AMERICAN PUBLIC HEALTH}

ASSOCIATION. APHA. Compendium of methods for the microbiological examination of foods. 4th ed. Washington: American Public Health Association, 2001. 676 p.

BANDEIRA, D.A.; CASTRO, R.S.; AZEVEDO, E.O. Características de produção da caprinocultura leiteira na Região do Cariri da Paraíba. Ciênc. Vet. Tróp., v.10, p.29-35, 2007.

BENNETT, RW.; LANCETTE, G.A. Bacteriological analytical manual. In: Staphylococcus. 8.ed. Maryland: FDA, 1998. Chap.12.

CARDOSO, M.V.; PINO, F.A.; FEDERSONI, I.S.P. et al. Caracterização da caprinocultura e ovinocultura no estado de São Paulo. Arq. Inst. Biol., v.82, p.1-15, 2015.

CARNICELLA, D.; AYRES, M.C.C.; LAUDADIO, V. et al. The effect of diet, parity, year and number of kids on milk yield and milk composition in Maltese goat. Small Ruminants Res., v.77, p.71-74, 2008.

CENSO agropecuário 2017: resultados preliminares. Rio de Janeiro: IBGE Disponível em: https://sidra.ibge.gov.br/pesquisa/censoagropecuario/censo-agropecuario-2017\#pecuaria. Acessado em: 07 fev. 2019. 
CORDEIRO, P.R.C.; BORGES, C.H.P.; BRESSLAU, S. Contagem de células somáticas de cabras leiteiras com ordenha manual e mecânica. In: CONGRESSO PANAMERICANO DE QUALIDADE DO LEITE E CONTROLE DE MASTITE. 2., 2002, Ribeirão Preto. Anais... Ribeirão Preto: [s.n.], 2002.

DONEY, J.M.; PEART, J.N.; SMITH, W.F. et al. A consideration of the techniques for estimation of milk yield by suckled sheep and a comparison of estimates obtained by two methods in relation to the effect of breed, level of production and stage of lactation. J. Agric. Sci., v.92, p.123-132, 1979.

FACÓ, O.; LÔBO, R.N.B.; SILVA, J.R.F.; SOUSA, W.H.; BOMFIM, M.A.D.; VILLELA, L.C.V. Teste de desempenho individual de reprodutores da raça Santa Inês: resultados da prova em Araripe, CE-2007. Sobral: Embrapa Caprinos, 2007. 28 p.

(Embrapa Caprinos. Documentos, 73).

FDA safety alert: needlestick and other risks from hypodermic needles on secondary I.V. administration sets - piggyback and intermittent I.V. Rockville, MD: FDA, 1992.

GOTTARDI, C.P.T.; MURICY, R.F.; SCHMIDT, M.C.V. Qualidade higiênica de leite caprino por contagem de coliformes e estafilococos. Ciênc. Rural, v.38, p.743-748, 2008.

IRANO, N.; REY, F.S.B.; TEIXEIRA, I.A.M.A. et al. Parâmetros genéticos para a produção de leite em caprinos das raças Saanen e Alpina. Rev. Ciênc. Agron., v.43, p.376-381, 2012.

MAIA, M.S.; GOMES, J.T.; SILVA, J.G.M. et al. Sistema de produção de caprino leiteiro para a agricultura familiar. Natal: EMPARN, 2010. $57 \mathrm{p}$.

MEDEIROS, E.J.L.; QUEIROGA， R.C.R.E.; MEDEIROS, A.N. et al. Sensory profile and physicochemical parameters of cheese from dairy goats fed vegetable oils in the semiarid region of Brazil. Small Ruminants Res., v.113, p.211-218, 2013.
MEDEIROS, L.F.D.; VIEIRA, D.H.; RODRIGUES, V.C. et al. Características de reprodução, peso ao nascer e mortalidade de caprinos Anglo-nubianos, no município do Rio de Janeiro I Fatores que afetam o período de gestação, fertilidade e prolificidade. Rev. Bras. Ciênc. Vet., v.13, p.37-43, 2006.

MIN, B.R.; TOMITA, G.; HART, S. Effect of subclinical intramammary infection on somatic cell counts and chemical composition of goats' milk. J. Dairy Res., v.74, p.24-210, 2007.

MOTA, D.M.; SÁ, C.O.; SÁ, J.L. Dinâmica recente no espaço rural do município de Nossa Senhora da Glória/SE. Rev. Bras. Agroecol., v.5, p.126-138, 2010.

MOURA, J.F.P. Análise tecnológica e sócioeconômica da produção de leite bovino no Cariri da Paraíba. Areia-PB: Universidade Federal da Paraíba, 2009. 105F. Tese (Programa de Doutorado Integrado em Zootecnia) Universidade Federal da Paraíba, PB.

NASCIMENTO, P.M.P.; SOUZA, J.M.G. Alternativas para contornar a estacionalidade reprodutiva de cabras leiteiras. In: FONSECA, J.F. (Ed.). Produção de caprinos e ovinos de leite. Juiz de Fora: Embrapa, 2011.

PARK, Y.W. Relative buffering capacity of goat milk, cow milk, soy-basead infant formulas, and comercial non-prescription antiacid drugs. $J$. Dairy Sci., v.74, p.3326-3333, 1991.

PRESCOTT, S.C.; BREED, R.S. The determination of the number of body cells in milk by a direct method. J. Infect. Dis., v.7, p.632-640, 1910.

RICHARDS, N.S.P.S.; PINTO, A.T.; SILVA, M.E. et al. Avaliação físico-química da qualidade do leite de cabra pasteurizado comercializado na Grande Porto Alegre, RS. Rev. Inst. Laticínios Cândido Tostes, v.56, p.217220, 2001.

RIET-CORREA B., SIMÕES S.V.D., PEREIRA FILHO J.M. et al. Sistemas produtivos de caprinocultura leiteira no semiárido paraibano: caracterização, principais limitantes e avaliação de estratégias de intervenção, Pesq. Vet. Bras, V.33. N.3, p.345-352, 2013 
SANTOS, C.M.S.; SANTANA, A.F. Produção de leite e duração da lactação de cabras da raça Pardo-alpina no município de Amélia Rodrigues - BA. Pubvet, v.5, p.1162-1170, 2011.

SILVA, D.S.; MEDEIROS, A.N. Eficiência no uso dos recursos da caatinga: produção e conservação. In: SIMPÓSIO INTERNACIONAL DE CAPRINOS E OVINOS DE CORTE. 2003, João Pessoa. Anais... João Pessoa, PB: Gráfica União, 2003. p.189-215.

SIMÕES, A.R.P.; OLIVEIRA, M.V.M.; LIMAFILHO, D.O. Tecnologias sociais para o desenvolvimento da pecuária leiteira no assentamento rural Rio Feio em Guia Lopes da Laguna, MS, Brasil. Interações, v.16, p.163-173, 2015.
TECNOLOGIAS para produção de leite na Região Semiárida do Brasil. Brasília: Embrapa, 2014. (Gado de leite).

THIENPONT, D.; ROCHETTE, F.; VANPARIJS, O.F.J. Diagnóstico de las Helmintiasis por medio del examen coprológico. Beerse, Bélgica: Janssen Research Foundation, 1986. 205p.

TRONCO, M. Manual para inspeção da qualidade do leite. 3.ed. Santa Maria: UFSM, 2008. 